\title{
Self-Concept Influences the Hopes and Psychological Well- Being of Cancer Survivors in Surabaya, Indonesia: A Cross- Sectional Study
}

\author{
Yesiana Dwi Wahyu Werdani \\ Faculty of Nursing, Widya Mandala Catholic University Surabaya, Indonesia
}

\section{ARTICLE INFO}

Received : 16 November 2019

Reviewed : 23 December 2019

Accepted : 15 April 2020

Keywords:

cancer survivor, hope, psychological

well-being, self-concept

\author{
A BSTRACT
}

\begin{abstract}
Background: The stigma of cancer as a deadly disease greatly affects the patient's perspective in shaping self-concept, which impacts on hopes and influences the stability of psychological well-being. The purpose of this study was to prove that the self-concept influences the hopes and psychological well-being of cancer survivors.
\end{abstract}

\begin{abstract}
Methods: This was a cross-sectional study. Samples were 90 cancer survivors from three public health centers in Surabaya, Indonesia taken by simple random sampling. All participants completed the instruments of the Tennessee Self-Concept Scale, Herth Hope Index, and Ryff's Psychological Well-Being Scale. All the instruments were valid and reliable based on the test. Ethical feasibility has been conducted. The Pearson Product-Moment Correlation Test was applied to analyze the data with $P<.05$.
\end{abstract}

\begin{abstract}
Results: The demographic characteristics of cancer survivors include the age majority of 46-65 years (53\%), female sex (80\%), married (61\%), having stage-III cancer (44\%), diagnosed of cancer for 1-6 years (56\%), having support system from nuclear families $(73 \%)$, and actively involved in the community (66\%). The mean score of self-concept is 78.2 , hope 38.2 , and psychological wellbeing 76.3. Self-concept had a significant effect on hope $(r=.783, P=.000)$ and psychological well-being $(r=.611, P=.000)$
\end{abstract}

Conclusions: Cancer survivors who had positive self-concepts are more likely to accept themselves, which triggers the formation of high hope for recovery and the achievement of positive psychological well-being.

\author{
*Corresponding author: \\ Yesiana Dwi Wahyu Werdani \\ Faculty of Nursing Widya Mandala \\ Catholic University Surabaya, \\ Indonesia \\ ywerdani@yahoo.com
}

\section{INTRODUCTION}

The stigma of cancer as a deadly disease greatly influences the point of view of people on the cancer disease. One study mentioned that the majority of cancer patients automatically think about death [1]. Cancer stigma is caused by the ability of cancer cells to metastasize and replicate without control and the side effects of therapy which significantly affect physical function disorders. The health team is also pessimistic about the prognosis of cancer, especially if the patient is found at an end-stage [2]. Other people's opinions of cancer can affect the patient's self-concept dimensions. Individual relationships with others can form positive and negative self-concepts. It affects the patient's expectations of life. The previous study stated that in cancer patients, there was a positive relationship between hopes and self-esteem [3]. When individuals feel life is meaningless, then there is only pessimism and despair in their life. If the condition lasts a long time, it will reduce the physical function of cancer patients and can lead to death. A study stated that most patients have experienced high levels of stress at the start of being diagnosed, 6 months, and even 1 year after being diagnosed. This high-stress level also has a high anxiety score [4]. A study explained that $39 \%$ of cancer patients suffer severe emotional distress and have a significant relationship with the patient's functional status [5].

GLOBOCAN 2018 estimated the incidence and deaths from cancer in 20 regions of the world; there would be around 18.1 million new cancer cases (17.0 million excluding non-melanoma skin cancer) and 9.6 million cancer deaths (9.5 million excluding cancer nonmelanoma skin) in 2018. The main causes of death were lung cancer ( $18.4 \%$ of total cancer deaths), followed by female breast cancer $(11.6 \%)$, prostate cancer $(7.1 \%)$ and colorectal cancer (6.1\%), gastric cancer (8.2\%), and liver cancer $(8.2 \%)$. Cancer is most often diagnosed, and the leading cause of death from cancer substantially 
varies in each country [6]. The prevalence of cancer in Southeast Asia in men is $16.3 \%$ and in women $14.52 \%$. Lung cancer is the highest prevalence in Southeast Asia at $35.9 \%$; breast cancer has an incidence of $38.1 \%$ with a mortality rate of $14.1 \%$; cervical cancer has an incidence of $17.2 \%$ with a mortality rate of $10 \%$; prostate cancer prevalence is $12.7 \%$ [6].

Negative testimonials from other cancer patients cause the formation of pessimism towards hopes, which can cause frustration and reduce self-esteem. The previous study stated that the hopes score was negatively related significantly to age. This occurs in oncology patients over 65 years of age; they have much lower hope than those under 65 years [7]. Previous studies on kidney cancer patients mentioned that the majority of patients experienced frustration with their diagnoses and fear of recurrence or development of cancer and financial problems due to cancer treatment [8]. Other studies further explained that self-concept with 3 sub-variables including body image, self-esteem, and self-efficacy affects emotional well-being in breast cancer patients in the form of anxiety and depression [9]. Cancer patients have negative body image, health evaluation, and disease orientation [10]. The hope possessed by someone has an impact on his psychological well-being. Cancer patients, who are unable to accept themselves and do not have a good relationship with others, tend to have poor psychological well-being. Impaired fulfillment of a patient's basic needs has a long-term impact on his psychological well-being [11]. The purpose of this study was to prove that the selfconcept influences the hopes and psychological wellbeing of cancer survivors.

\section{METHODS}

This was a cross-sectional study. The populations were 118 cancer survivors in three public health centers in Surabaya, Indonesia who have completed a series of cancer therapies. The samples included 90 cancer survivors taken by simple random sampling. The period for this research was on March-May 2019. The instrument used has been tested for validity and reliability, resulting in the Tennessee Self-Concept Scale of R 0.607-0.949 and Cronbach's alpha score of 0.966, Herth Hope Index of R 0.548-0.949, Cronbach's alpha score of 0.928 , Ryff's Psychological Well-Being Scale of R 0.608-0.935, and Cronbach's alpha score of 0.965 . The ethical test was conducted by Ethical Foundation, and this study was declared ethical with certificate number 003/WM12/KEPK/T/2019. The researcher has explained the research purposes, benefits, procedures, risk, and research confidentiality as the research ethics requirement. The participants who were willing and agreed to be involved in the research signed the informed consent. All the participants completed the three instruments. The assessment of each questionnaire was done by calculating the scores; the score obtained is more than half of the score range, it is categorized as the high score, which means positive self-concept, high hopes, and positive psychological well-being; if it is less than half of the score range it means, it is categorized as the low, which means negative selfconcept, low hope, and negative psychological wellbeing. The score range of self-concept is $25-100$, hope 12-48, and psychological well-being $24-96$.

After the data had been collected, the next step was to analyze the normality test using the One-Sample Kolmogorov-Smirnov Test. Normally-distributed data is a requirement for the Pearson Product Moment Correlation Test. The last statistic test was the Pearson Product Moment Correlation to correlate self-concept on the hopes and psychological well-being.

\section{RESULTS}

Table 1: Demographic characteristics $(n=90)$

\begin{tabular}{|c|c|c|c|}
\hline Demographic Data & Category & $\mathbf{n}$ & $\%$ \\
\hline \multirow[t]{4}{*}{ Age (years) } & 17-25 (adolescent) & 4 & 5 \\
\hline & 26-45 (adulthood) & 11 & 12 \\
\hline & 46-65 (older adult) & 48 & 53 \\
\hline & $>65$ (elderly) & 27 & 30 \\
\hline \multirow[t]{2}{*}{ Gender } & Female & 72 & 80 \\
\hline & Male & 18 & 20 \\
\hline \multirow[t]{4}{*}{ Marital status } & Single & 11 & 12 \\
\hline & Married & 55 & 61 \\
\hline & Widow & 23 & 26 \\
\hline & Widower & 1 & 1 \\
\hline \multirow[t]{4}{*}{ Cancer stage } & 1 & 7 & 8 \\
\hline & II & 31 & 34 \\
\hline & III & 40 & 44 \\
\hline & IV & 12 & 14 \\
\hline \multirow{4}{*}{$\begin{array}{l}\text { Duration of cancer } \\
\text { diagnosed (year) }\end{array}$} & $<1$ & 20 & 22 \\
\hline & $1-3$ & 25 & 28 \\
\hline & $4-6$ & 25 & 28 \\
\hline & $>6$ & 20 & 22 \\
\hline \multirow[t]{4}{*}{ Support system } & Nuclear families & 65 & 73 \\
\hline & Extended families & 12 & 12 \\
\hline & Others & 8 & 9 \\
\hline & Alone & 5 & 6 \\
\hline \multirow{2}{*}{$\begin{array}{l}\text { Community } \\
\text { activities } \\
\text { involvement }\end{array}$} & Active & & 66 \\
\hline & Not Active & $\begin{array}{l}59 \\
31\end{array}$ & $\begin{array}{l}66 \\
34\end{array}$ \\
\hline
\end{tabular}

Based on Table 1, most participants were older adults in the age range of 46-55 years old and dominated by the female and married status. The most cases were of stage-III cancer. Many participants had cancer diagnosed for 1-6 years. Nuclear families were 
involved in caring as a support system, and the majority of participants were actively involved in community activity.

Table 2: Descriptive statistic between self-concept, hopes and psychological well-being

\begin{tabular}{lccccc}
\hline Variable & $\mathbf{n}$ & Min & Max & Mean & SD \\
\hline Self-Concept & 90 & 57.00 & 95.00 & 78.2 & 7.5 \\
Hopes & 90 & 29.00 & 47.00 & 38.2 & 4.1 \\
$\begin{array}{l}\text { Psychological } \\
\text { Well-being }\end{array}$ & 90 & 59.00 & 90.00 & 76.3 & 7.6 \\
\hline
\end{tabular}

Based on Table 2, the mean score of self-concept was 78.2, hope 38.2, and psychological well-being 76.3. All of the mean scores reached more than half the score range (score range of self-concept was 25-100, hope 12-48, psychological well-being 24-96). It means that almost all the participants had a positive self-concept, high hope, and positive psychological well-being.

Table 3: The normality test of self-concept, hopes, psychological well-being

\begin{tabular}{lc}
\hline Variable & One Sample Kolmogorov Smirnov \\
\hline Self-Concept & $p=.071$ \\
Hopes & $p=.227$ \\
Psychological Well-Being & $p=.070$ \\
\hline
\end{tabular}

Based on Table 3, all variables had normally -distributed data with $P>.05$. The $P$-value of the selfconcept variable was 0.071 , hope 0.227 , and psychological well-being 0.070 .

Table 4: Pearson product moment correlation test of variable self-concept and hopes and psychological well-being

\begin{tabular}{llll}
\hline $\begin{array}{l}\text { Independent } \\
\text { Variable }\end{array}$ & $\begin{array}{l}\text { Pearson Product } \\
\text { Moment } \\
\text { Correlation Test }\end{array}$ & Hopes & $\begin{array}{l}\text { Psychological } \\
\text { well-being }\end{array}$ \\
\hline Self-Concept & Pearson correlation & 0.783 & 0.611 \\
& $p$ & 0.000 & 0.000 \\
\hline
\end{tabular}

Based on Table 4, there was a significant correlation between self-concept, hope, and psychological wellbeing. It means that self-concept influences hope and psychological well-being significantly.

\section{DISCUSSION}

The result in Table 2 showed that most participants had high scores of self-concept, which is more than half of the range score of self-concept. It means that the self-concept was positive. An individual with a positive self-concept is more likely to change unhealthy habits to improve health than an individual with a negative self-concept. Positive feelings about themselves help individuals to overcome crises in various situations even when they suffer from life-threatening diseases such as cancer [9]. One factor contributed to this result that all participants were cancer survivors who had been finishing the complex therapeutic processes. After undergoing cancer therapy, various physical complaints decreased, and the patient's condition is getting better. It was supported by another study that physical condition, cognitive function, and emotion increased significantly after the treatment and so did fatigue, pain, insomnia, and loss of appetite [12]. Other researchers stated that cancer survivors had experienced more positive psychological and physical adjustments after undergoing medical treatment [13]. The positive selfconcept findings in this study have a significant correlation with age, that is most respondents are older adults. A study in line with these findings states that the self-concept of an older person is better than the younger one [14].

Passed the critical stage will make cancer survivors have a strong personality and more confidence. A prior study reported that the average score for self-confidence in patients with a terminal disease was better when they finished the therapy management [15]. Positive self-concept arises from a high sense of optimism. Cancer patients with a high degree of optimism will adapt to their disease better than pessimistic patients [16]. A good adaptation process was found in patients who had been diagnosed with the disease for a long time. Table 1 shows that most participants have been diagnosed with cancer for more than 1 year. Suffering illness for a long time, cancer patients can adapt to the situation and accept the condition more easily. Cancer survivors who can survive until the second year have the potential to be able to surpass the following days better [17] and can recover from physical and psychological trauma [18]. Most cancer patients after 6 months of being diagnosed with cancer and undergoing treatment were found to able to return to work [19].

Table 2 shows that the score of hope is also high, more than half of the score range of hope, and Table 4 shows that there is a significant influence of self-concept on participant's hope. Hope is an important element in chronic diseases that can help patients adhere to treatment for better success [20]. According to cancer survivors, hope is one's desire to lead a normal life, get social support, actively relinquish control, and accept life and death [21]. Hope can arise from external supports such as family and social supports [22]. The same thing was mentioned by another study that hope has a significant value with family support [23]. This is 
in line with the results of this study that most participants are married and live with nuclear families. Patients who are married and live with their families have more material, psychological, and spiritual supports, which can increase their hopes. A study of breast cancer survivors stated that married status has a more positive influence on the psychological function [24]. The family caregiver was eager to be involved in the patient care process, desired to accompany the patient, to provide the positive respect needed by the patient [25], to provide and build good communication with the patient [26], and to provide positive support to the patient [27]. Besides that, hope is also formed from interactions with other people or the community. A study mentioned that intense interaction with neighbors can help increase hope in people who experience depression or posttraumatic stress symptoms [28]. The findings of this study are similar as in Table 1 that shows most participants are involved in activities in the community. Social support provided by the community makes individuals more confident, feel accepted, and valued so that they can improve their enthusiasm for life [29]. Social support provided by the community can increase optimism and positive feelings [30].

The mechanism of the emergence of hope is obtained through the impact of the disease on health and is a protective effect from stress in the hope that it will prevent someone from bad effects [31]. The participants in this study perceived that cancer patients must have the hope of recovery because it can motivate them to survive and make a better life. A study reported that the majority of cancer patients have high hope [23]. Patients who had high optimism reported better health status and had greater happiness and hope [32].

Table 2 shows that the score of psychological wellbeing is also high, more than half of the score range of psychological well-being, which means most participants have positive psychological well-being. Meanwhile, Table 4 describes that there is a significant influence of self-concept on the participant's psychological well-being. Being optimistic also has a positive effect on psychological well-being. A study in cancer patients stated that there was a positive relationship between optimism and psychological well-being and there was a negative relationship between optimism, pressure, and depression [33]. Significantly-higher levels of optimism are associated with fewer anxiety and depression symptoms, a lack of hopelessness, and a better quality of life [34]. A study found that optimism is the strongest for the emergence of positive psychological well-being which can further produce positive health behaviors and biological functions [35]. One aspect of psychological welfare is eudaimonic wellbeing which includes the meaning, purpose in life, selfactualization, and autonomy [36]. The role, self-ideal, and self-identity are attributed to achieving self- actualization contained in self-concept. This is in line with the results of this study that participants who have positive self-concepts also have positive psychological well-being. Social relationships are also an element of psychological well-being [37]. This study also found the participant's involvement in community activities. A study states that social relationships provide a major influence on physical and mental health in patients who experience physical limitations [38,39]. Besides, a study also mentioned that family relationships also have a positive impact on reducing individual stress and increasing psychological well-being [40]. This is consistent with the findings in this study that most participants are supported by nuclear families.

The limitation of this study is that there were no restrictions regarding the stages of cancer. All stages of cancer were used as research samples which might contribute to the achievement of the results of this study.

\section{CONCLUSIONS}

Cancer survivors who have completed the cancer therapy program have a positive self-concept, which causes them to be more excited and optimistic about their lives. This can trigger the high hope to recover from illness and cause psychological well-being to be positive.

\section{DECLARATIONS}

\section{Competing interest}

I declare that I do not have any competing interests, especially with the study funder.

\section{Acknowledgement}

I greatly appreciate and thankful for the cooperation and assistance provided by the staff member and all of the participants from three Public Health Centers in Surabaya namely Kedungdoro Public Health Center, Pucangsewu Public Health Center, and Pacarkeling Public Health Center. I am also thankful to the dean Faculty of Nursing and Widya Mandala Catholic University as a funder who has contributed to the research that was done.

\section{REFERENCES}

1. Moser RP, Arndt J, Han PK, Waters EA, Amsellem M, Hesse BW. Perceptions of cancer as a death sentence: Prevalence and consequences. J Health Psychol. 2014;19(12):1518-24. 
2. Goldvaser H, Milman $Y$, Dujovni T, Stern A, Mahamid $M$, Hanovich $E$, et al. Perception of prognosis of cancer patients by non-oncologists. Int J Clin Pract. 2016;70(12):1027-32.

3. Parvan K, Jabbarzadeh Tabrizi F, Rahmani A, Ghojazadeh M, Azadi A, Golchin M. The relationship between hope and self-esteem in patients with leukemia. J Caring Sci. 2015;4(3):217-23.

4. Ng CG, Mohamed S, Kaur K, Sulaiman AH, Zainal NZ, Taib NA, et al. Perceived distress and its association with depression and anxiety in breast cancer patients. PLoS One. 2017;12(3):e0172975.

5. Saeedi-Saedi H, Shahidsales S, Koochak-Pour M, Sabahi E, Moridi I. Evaluation of emotional distress in breast cancer patients. Iran J Cancer Prev. 2015;8(1):36-41.

6. Bray F, Ferlay J, Soerjomataram I, Siegel RL, Torre LA, Jemal A. Global cancer statistics 2018: GLOBOCAN estimates of incidence and mortality worldwide for 36 cancers in 185 countries. CA Cancer J Clin. 2018;68(6):394-424.

7. Duggleby W, Ghosh S, Cooper D, Dwernychuk L. Hope in newly diagnosed cancer patients. J Pain Symptom Manage. 2013;46(5):661-70.

8. Bergerot $C D$, Battle $D$, Bergerot PG, George DJ, Hammers $\mathrm{HJ}$, Jonasch $\mathrm{E}$, et al. Frustration and distress during treatment for advanced renal cell carcinoma. J Clin Oncol. 2018;36(34_suppl):47-47.

9. Pintado S. Self-concept and emotional well-being in patients with breast cancer. Rev Iberoam Psicol y Salud. 2017;8(2):76-84.

10. Bahrami M, Mohamadirizi M, Mohamadirizi S, Hosseini S. Evaluation of body image in cancer patients and its association with clinical variables. J Educ Health Promot. 2017;6(1):81.

11. Lehto U-S, Helander S, Taari K, Aromaa A. Patient experiences at diagnosis and psychological well-being in prostate cancer: A Finnish national survey. Eur J Oncol Nurs. 2015;19(3):220-9.

12. Dahiya N, Acharya AS, Bachani D, Sharma D, Gupta S, Haresh K, et al. Quality of life of patients with advanced cervical cancer before and after chemoradiotherapy. Asian Pac J Cancer Prev. 2016;17(7):3095-9.

13. Stanton AL, Rowland JH, Ganz PA. Life after diagnosis and treatment of cancer in adulthood cancer and psychology special issue. Am Psychol. 2015;70(2):15974.

14. Diehl M, Hay EL. Self-concept differentiation and self-concept clarity across adulthood: Associations with age and psychological well-being. Int J Aging Hum Dev. 2011;73(2):125-52.

15. Sehati Shafaee F, Mirghafourvand M, Harischi S, Esfahani A, Amirzehni J. Self-confidence and quality of life in women undergoing treatment for breast cancer. Asian Pac J Cancer Prev. 2018;19(3):733-40.
16. Thieme M, Einenkel J, Zenger M, Hinz A. Optimism, pessimism, and self-efficacy in female cancer patients. Jpn J Clin Oncol. 2017;47(9):849-55.

17. Sugimura $H$, Yang $P$. Long-term Survivorship in Lung Cancer. Chest. 2006;129(4):1088-97.

18. Andrykowski MA, Lykins E, Floyd A. Psychological health in cancer survivors. Semin Oncol Nurs. 2008;24(3):193-201.

19. de Boer AGEM, Verbeek JHAM, Spelten ER, Uitterhoeve ALJ, Ansink AC, de Reijke TM, et al. Work ability and return-to-work in cancer patients. Br J Cancer. 2008;98(8):1342-7.

20. Ghazavi Z, Khaledi-Sardashti F, Kajbaf MB, Esmaielzadeh M. Effect of hope therapy on the hope of diabetic patients. Iran J Nurs Midwifery Res. 2015;20(1):75-80.

21. Mok E, Lam WM, Chan LN, Lau KP, Ng JS, Chan KS. The meaning of hope from the perspective of Chinese advanced cancer patients in Hong Kong. Int J Palliat Nurs. 2010;16(6):298-305.

22. Li MY, Yang YL, Liu L, Wang L. Effects of social support, hope, and resilience on quality of life among Chinese bladder cancer patients: A cross-sectional study. Health Qual Life Outcomes. 2016;14:73.

23. Abdullah-Zadeh F, Agahosseini S, Asvadi-Kermani I, Rahmani A. Hope in Iranian cancer patients. Iran J Nurs Midwifery Res. 2011;16(4):288-91.

24. Tessier P, Lelorain S, Bonnaud-Antignac A. A comparison of the clinical determinants of healthrelated quality of life and subjective well-being in long-term breast cancer survivors. Eur J Cancer Care. 2012;21(5):692-700.

25. Fateel EE, O'Neill CS. Family members' involvement in the care of critically ill patients in two intensive care units in an acute hospital in Bahrain: The experiences and perspectives of family members' and nurses' - A qualitative study. Clin Nurs Stud. 2015;4(1).

26. Walseth LT, Schei E. Effecting change through dialogue: Habermas' theory of communicative action as a tool in medical lifestyle interventions. Med Heal Care Philos. 2011;14(1):81-90.

27. Yektatalab S, Sharif F, Kaveh MH, Fallahi Khoshknab $M$, Petramfar $P$. Living with and caring for patients with Alzheimer's disease in nursing homes. J Caring Sci. 2013;2(3):187-95.

28. Cheng Y, Li X, Lou C, Sonenstein FL, Kalamar A, Jejeebhoy $S$, et al. The association between social support and mental health among vulnerable adolescents in five cities: Findings from the study of the well-being of adolescents in vulnerable environments. J Adolesc Heal. 2014;55(6):S31-8.

29. Ikeda A, Kawachi I, Iso $H$, Iwasaki $M$, Inoue $M$, Tsugane S. Social support and cancer incidence and mortality: The JPHC study cohort II. Cancer Causes Control. 2013;24(5):847-60. 
30. Hodges K, Winstanley S. Effects of optimism, social support, fighting spirit, cancer worry, and internal health locus of control on positive affect in cancer survivors: A path analysis. Stress Heal. 2012;28(5):408-15.

31. Madan S, Pakenham KI. The Stress-Buffering Effects of Hope on Adjustment to Multiple Sclerosis. Int J Behav Med. 2014;21(6):877-90.

32. Taber JM, Klein WMP, Ferrer RA, Kent EE, Harris PR. Optimism and Spontaneous Self-affirmation are Associated with Lower Likelihood of Cognitive Impairment and Greater Positive Affect among Cancer Survivors. Ann Behav Med. 2016;50(2):198-209.

33. Horney DJ, Smith HE, McGurk M, Weinman J, Herold $\mathrm{J}$, Altman $\mathrm{K}$, et al. Associations between quality of life, coping styles, optimism, and anxiety and depression in pretreatment patients with head and neck cancer. Head Neck. 2011;33(1):65-71.

34. Applebaum AJ, Stein EM, Lord-Bessen J, Pessin H, Rosenfeld B, Breitbart W. Optimism, social support, and mental health outcomes in patients with advanced cancer. Psychooncology. 2014;23(3):299-306.
35. Boehm JK, Kubzansky LD. The heart's content: The association between positive psychological well-being and cardiovascular health. Psychol Bull. 2012;138(4):655-91.

36. Deci EL, Ryan RM. Hedonia, eudaimonia, and well-being: An introduction. J Happiness Stud. 2008;9(1):1-11.

37. Feller SC, Castillo EG, Greenberg JM, Abascal P, Mdiv $\mathrm{RVH}$, Wells KB, et al. Emotional well-being and public health: Proposal for a model national initiative. Public Health Rep. 2018;133(2):136-41.

38. Umberson D, Karas Montez J. Social Relationships and Health: A Flashpoint for Health Policy. J Health Soc Behav. 2010;51(1_suppl):S54-66.

39. Tough H, Siegrist J, Fekete C. Social relationships, mental health and wellbeing in physical disability: A systematic review. BMC Public Health. 2017;17(1):414.

40. Thomas PA, Liu $H$, Umberson D. Family Relationships and Well-Being. Innov Aging. 2017;1(3). 